\title{
Are Reasons Causally Relevant for Action? Dharmakirti and the Embodied Cognition Paradigm
}

Christian Coseru

For Dharmakìrti - the influential seventh-century Indian Buddhist philosopher who, along with his predecessor Dignāga (480-540 CE), serves as a founding figure of the Buddhist logico-epistemological school - there is a special relationship between reasons and causes: specifically, Dharmakirti and some of his followers, like many contemporary philosophers of a more naturalist persuasion, put forward the view that intuitions about causal chains of events can serve as reasons for effective action. The leading question of this essay is whether Dharmakirti's account of reasoning could contribute to current debates in epistemology and philosophy of action. I will not address, therefore, exegetical questions about whether what we are dealing with here is some kind of sui generis naturalism, serious metaphysics, or something completely different. ${ }^{1}$ Instead, what I propose to do is ask a series of questions about the relation between reasons and causes at work in Dharmakirti's kāryānumāna argument (that is, the argument that an inference is sound only when one infers from the effect to the cause and not vice versa), and derive some conclusions about whether or not Dharmakirti shares a common concern with current practitioners of naturalized epistemology.

\section{Causality, Intentionality, and Mental Content}

Dharmakirti's work can be seen as extending the metaphysical and phenomenological concerns of Abhidharma, with its focus on mapping out the structure of our cognitive architecture and the function of its various constitutive elements (perception, attention, intentionality, etc.). By advancing a conception of causation that includes consciousness and cognition as causal efficient categories, Abhidharma presents us with a metaphysics of experience: the irreducible elements of existence (dharmas) are not essences or substances, but activities, properties, and patterns of connectedness. ${ }^{2}$ The project of 
identifying and mapping out these irreducible elements (e.g., sensation, volition, attention, memory) shares many of the concerns of embodied and enactive cognitive science, even as it lacks the latter's empirical foundation.

One way to frame Dharmakirti's project is as an attempt to situate these early Abhidharma explorations of the function of consciousness and cognition on a firm epistemological basis. Given a general concern with examining the sources of reliable cognition, Dharmakirti's epistemological orientation (much like that of his predecessor, Dignāga) is naturalistic. Indeed, he articulates his account of language and inferential reason (as circumscribed by his apoha theory) largely on a model of embodied cognition, not unlike that pioneered in the work of Varela, Thompson, and Rosch $(1991) .^{3}$ As a systematic inquiry into the foundations of knowledge, Buddhist epistemology thus aligns closely with contemporary naturalized epistemology. For the purpose of this analysis, I take naturalism to be a commitment to considering the empirical evidence from the sciences of cognition in settling questions about the acquisition of beliefs. ${ }^{4}$ More broadly, naturalism refers to the notion that reality is exhausted by nature, although the question whether "nature" should include the mental is itself a part of a long-standing philosophical debate. Philosophers with weak commitments to naturalism typically operate with rather unrestricted notions of nature, whereas stronger adherents to naturalism define it more stringently. My position on naturalism, which I defend at length elsewhere, ${ }^{5}$ closely aligns with the so-called 4E (embodied, enactive, embedded, and extended) approach to cognition: cognitive awareness is to be thought of not as an internal state of mind or brain locked into linear causal chains of sensory input and behavioral output. Rather, it is to be understood as a structure of comportment, an intentional and self-disclosing orientation and attunement to a world of actions, objects, and meaning.

Closely related to the question of how the intentionality or directness of mental states is at all possible is a more difficult question: How do mental states acquire their intentional content? That is, how do mental states come to be about something other than their own operations, and thus to serve as ground for effective action? No satisfactory answer to this question can circumvent debates about externalism versus internalism in epistemology. The question that I will pursue here, however, is more specific (and more apt to cut across this debate): Can such intentional content, in turn, play a causal role in explaining how acting toward some end is successfully accomplished? Specifically, if the justification for pursuing a certain course of action and the ensuing disposition to act are not simply outcomes of post hoc rationalization but integral elements of the causal web of events, then different chains of justification do not simply explain but enact different outcomes.

On the surface, it may seem as though this way of framing the problem of the relation between reasons and causes is trivial. Of course, thinking about raising my hand can cause my hand to go up. But insofar as actions are grounded in 
the physical biological processes that realize them, it is not at all clear how and where reasons fit in the causal web. What makes Dharmakirti's proposed solution to this conundrum interesting is not just his argument that reasons are causes (or, at least, are causally relevant for action), but his attempt to defend it on a strictly Abhidharmic (that is, reductionist) understanding of causation (on the model provided by the causal principle of dependent arising). If events arise due to a multitude of causes and conditions, then, the phenomenal primitives that mental states reduce to must play a constitutive role in the arising of these events. Buddhist moral psychology attests to the possibility of overcoming habitual modes of behavior. As such, it also provides reasons for valuing a certain course of action (viz., the Noble Eightfold Path), and expected outcomes (e.g., the goods that all Buddhist adepts seek). If, as Dretske $(1989,2)$ claims, reasons help us "to explain why we should do some of the things we do," then they are the causes for doing some of the things we do (even as they do not make explicit how our doings are behaviorally achieved).

One possible objection to this line of inquiry would be to say that the reductionist models of cognitive science differ in significant ways from those which are at work in the Abhidharma. The former are rooted in a variety of accounts of cognition in terms of functionalist, computational, and neurobiological models, to cite but a few, which may or may not be intertheoretically reducible. The latter offer at best a mereological account of whole-part relations, in which more complex entities (e.g., chairs) and cognitive events (e.g., pains) are explained in terms of either externally conditioning factors (material elements) or internally dispositional constituents (phenomenal primitives). Since the only types of entities that are admitted to exist are those that cannot be further physically decomposed or dissolved through conceptual analysis, ultimately we are left with kind and quality terms. As Vasubandhu writes in the Abhidharmakośa: "When the apprehension of an entity persists after that entity has been reduced through conceptual analysis, that entity exists ultimately, e.g., form: while form may be reduced to atoms, and while we may exclude from it through cognitive analysis other qualia (such as taste, etc.), the apprehension of the proper nature of form persists" (Pradhan 1975, 334).

The Abhidharma tradition thus understands causality not in terms of relations between elements and compounds but in terms of a tripartite action-objectagent or cognition-cognized-cognizer model (pramiti-prameya-pramātṛ). It is this model of cognition that informs the view of Buddhist epistemologists such as Dharmakīrti.

A more serious objection comes in the form of arguments that invoke the causal closure of the physical domain as providing justification for treating mental events as causally inert. Although responses to this line of argumentation can vary widely, the notion that, as Dretske puts it, "what we believe, intend, and desire has no bearing on what we do" (Dretske 1989, 3) is deeply problematic. One solution is found in token-identity theories of the mental, 
which argue for the causal efficacy of mental events insofar as they are tokenidentical to physical events, a view known as anomalous monism (cf. Davidson 1970). The approach I favor follows closely Lowe's (2008) view that causation in the mental domain functions on principles of intelligibility (that is, on principles which make it perfectly intelligible for intentions to have a causal role in initiating behavior) rather than principles of mechanism (that is, on principles which explain how causation works in the physical domain). Mental events, thus, should be understood as causing actions not physical effects, since actions are not the sort of things studied by the natural sciences. Those actions will have their behavioral signatures when enacted, but as actions they cannot be understood in purely behavioral terms.

We can easily answer the first objection either by showing that the reductionist model of cognition at work in the Abhidharma is open to revision, or by pointing to embodied and embedded models of cognition to show that not all cognitive science is eliminativist. The second objection, as already noted, is considerably more difficult, in part because it invokes the casual closure of the physical domain as evidence for the epiphenomenal character of mental states. My proposed solution comes in the form of a new kind of naturalism: call it phenomenological naturalism. As I have argued elsewhere (Coseru 2015), phenomenological naturalism provides a way to articulate the relation between phenomenology and the project of naturalization that neither eliminates the first-person givenness of experience, nor collapses all of nature into what is experientially available. On this view, intentional mental states and their contents are structural features of our cognitive architecture. Insofar as our cognitions attain their objects, their features both map out the range of possibilities that are available to us, and structure the causal process that guarantees the effectiveness of our actions. Cognitive events, which arise as a result of the tight causal coupling between perception, reflection, and action, then, are not causally inert. Rather, they are constituted as causally relevant factors in the determination of action.

\section{Cognition and Pragmatic Efficacy}

Let me start with a general characterization of the Buddhist epistemological enterprise (pramāṇavāda) as a manifest form of epistemological optimism. Epistemological optimism is, generally speaking, the view that at least a subset of our cognitive modalities are reliable, and that it is actually possible to provide an explanatory account of how such modalities provide effective guidance for our actions. If Dharmakīrti is an epistemological optimist, which I think he is, then he must be held to task: he must show, first, how perception (one of the only two sources of knowledge he deems reliable) gives access to real particulars, and, second, how linguistic and conceptual 
practices can be pragmatically efficacious, that is, how they can lead to successful action given his generally nominalist stance.

For the purpose of this analysis, I will mainly focus on the second question, which requires that we briefly unpack some of the key aspects of Dharmakirti's theory of inference. As is well known, Dharmakirti's arguments in support of providing a metaphysical basis for inductive reasoning, especially as presented in the Svārthānumana chapter of the Pramānavārttika (Dharmakīrti 1957), ${ }^{6}$ address a series of important and as yet unresolved issues regarding the foundational role of perception for knowledge. Resolving any of these issues would arguably have broader implications for our understanding and assessment of the nature and scope of the Buddhist epistemological enterprise.

I have two proposals here. My first is that we seek to understand Dharmakirti's innovative contributions to reasoning in epistemological rather than metaphysical terms: that is, in terms of how reasoning from evidence does and should proceed, rather than in terms of the justification of what kinds of things can be demonstrably said to exist. My second proposal is that we view Dharmakirti's causal account of knowledge in terms of a certain conception of cognition as dynamically constituted and, thus, as a mode of engagement with situations and things.

Let me start with a brief summary of Dharmakīrti's innovative contribution to inductive reasoning. In response to Dignāga's (allegedly failed) attempt to resolve the problem of induction by means of the triple inferential method (trairüpyahetu), Dharmakīrti formulates his well-known principle that reasoning from the empirical data must be grounded on more than the simple observation and non-observation of occurring associations and dissociations, following the established method of anvaya (association of the evidence with the property to be established through it) and vyatireka (dissociation of the evidence with the property to be established). Dharmakirti expands this method also to include a discussion of the paksadharmatā, the so-called evidence-subject relation, by means of which the trustworthiness of the former is established.

Consider the following key passage from Hetubindu 2.13 ("Drop of Reason" in Steinkellner 1967), in which the evidence-subject relation is spelled out in terms of the feature-placing power of reliable modes of apprehension:

As previously stated, certainty [about the evidence-subject relation] is how perception and inference establish a quality of the subject, which serves as a property to be proven, such as, for instance, the determination that smoke is present in a locus or that the quality of being a product applies to sound. Thus, by means of perception there is the experience of a smoke possessing place whose distinctive character differs from everything else in its uniqueness. Given perceptual acquaintance with that place, there is, in a subsequent moment, 
the cognition of evidence; this subsequent cognition is a type of recollection whose object is the difference [that enables the dissociation of smoke from non-smoke] on the basis of perceptual testimony.

Thus, when Dharmakīrti postulates that for a sound argument to obtain, two natural relations (between the evidence and what is to be established thereby) must be present, he is making a case for an enactive account of cognition. The two relations, of identity (tädātmya) and causal generation (tadutpatti), are effectively ways to state the token-identity of reasons and causes. Dharmakirti's answer to the question of how these two natural relations are to be ascertained is framed by his defense of core Buddhist metaphysical principles, in this case, chiefly that of momentariness. It is here that Dharmakirti's text raises three important issues concerning the nature of evidence and the role of perception in disclosing something essential about the order of the chain of events in the empirical domain. First, what is the nature of evidence or, more specifically, of the evidential property (hetu) for the thesis, or that which is to be established $(s \bar{a}$ dhya)? Second, what would be the implication of asserting that the truth of the major premise can be known by perception? And finally, can a careful inspection of the effect, in the case of Dharmakīrti's käryānumāna argument, be conducive to ascertaining the unique causal totality that is its source?

The answer to the first question is clear: only the two natural relations of identity and causal generation can serve as evidential property for the thesis. I will turn to these in a moment. The second question does not invite a straightforward answer. As Richard Hayes and Brendan Gillon (2008, 362) have recently explained, to claim that one can know the truth of the major premise by perception amounts to saying that whatever conclusion one may arrive at through inferential reasoning can also be known by perception. On this account, then, inferential reasoning would become a redundant source of knowledge.

As I have argued at length elsewhere (Coseru 2012, 115), it needn't be so, and this is where I think a naturalized account of reasons comes in handy: indeed, inferential reasons turn both toward ideal objects and toward the subjective modes of apprehension that ground our thought. When a proposition of the sort "sound is impermanent, because it results from effort" is judged true, it becomes true, logically speaking, once and for all such that its opposite is false. However, the problem is that "once and for all," or "perpetually" (nityam), is a subjective locution that belongs to the subjective experience of temporality. Furthermore, for any given system of reasoning, when we try to establish the truth of a proposition we invariably find ourselves having to turn away from the actual structure of the argument and appeal to experience or to a coherent system of beliefs (at least on a coherentist theory of truth). Models of embodied and embedded cognition developed in the last three decades ${ }^{7}$ (and their adaptations in the Buddhist context ${ }^{8}$ ) suggest that perception is not simply a 
passive mode of apprehending objects and properties in the empirical domain - or what the Buddhist calls "unique particulars" - but an active process of involvement with situations and things. ${ }^{9}$

This need for grounding reason in experiential access to some presumably irreducible given (or to the givenness of experience itself) does not necessarily imply that Dharmakirti is an epistemological foundationalist. ${ }^{10}$ Here I want to make a different sort of claim, one that may suggest a bold answer to the third question: namely, that careful scrutiny of the effect can provide a basis for ascertaining the unique causal totality that is its source, but only for reasoning that is context-specific. I am prompted, thus, to ponder whether the inferential model at work in the Buddhist epistemological literature is best described as a system of pragmatic or context-dependent reasoning. Unlike deductive systems of semantic reasoning, which are context-free, pragmatic reasoning is largely inductive and encompasses the types of logic (nonmonotonic and paraconsistent) that represent reasoning from premises that are context-specific. On this model of pragmatic reasoning, while a given sentence $\varphi$ may be a pragmatic consequence of a set of premises $\varphi$ it need not be a pragmatic consequence of a larger set of premises $\varphi \cup \Psi{ }^{11}$

Indeed, following Dignāga's inductive model of reasoning, we reason by first observing the occurrence of certain properties in an object or class of objects and the non-occurrence of those same properties when the object is absent. We establish that in order for a linguistic utterance to acquire the status of logical proof, the reason (hetu) must be present in the thesis (that is, in the position that is stated), be also present in similar positions, and be absent from all dissimilar positions. This is Dignāga's well-known model of the triple inferential mark (trairüpya), which operates by deriving hypothetical statements from past observations of the inductive domain. Consider again the example of produced phenomena such as sound: sound is impermanent because it is a product, and whatever is produced exists by virtue of its supporting causal and conditioning factors and ceases to exist with the cessation of its support. Conversely, a permanent object cannot be produced. That is, arguably, how we arrive at a logical reason. Thus, a proposition of the type "Sound is impermanent, because it results from effort" is true so long as we do not encounter an example of permanent, hence unproduced, sounds. Were we to come across such a counter-example, the proposition will be falsified. $^{12}$

Now, Katsura has defined this type of logic as "hypothetical reasoning based on induction" (Katsura 2007, 76), claiming that while reasoning for oneself is essentially inductive, the presentation of arguments to others follows the deductive path. Indeed, to the extent that this system of reasoning, which is based on the observation and non-observation of evidence, is open to revision so as to accommodate cases where there is a violation of the linguistic convention, we may describe it as a system of pragmatic reasoning. 
Dharmakirti's attempt to ground reasoning on a stronger principle than mere observation and non-observation of the evidence led him to postulate that there must be some "essential connection" (svabhāvapratibandha) between the thesis and what is to be demonstrated. Although this essential connection is meant to address the problem of the uncertainty of hypothetical reasoning, it is not pragmatically neutral, since Dharmakīrti's ultimate criterion for truth is the causal efficacy of cognitions (arthakriyā).

\section{A Theoretical Model for Causal Inference}

Let's take a closer, if brief, look at Dharmakïrti's descriptive analysis of the role of causation for inference, as found in his principal work, the Pramannavarttika II.11-38, and its autocommentary, the Svopajñavrtti (hereinafter abbreviated as PVSV; Pandeya 1989). First, in order to establish the sort of evidence that can serve as a warrant for sound inference and, at the same time, to rule out those instances of erratic attribution of a connection between evidence and the property to be proven, Dharmakirti avails himself of various examples of things that are ordinarily thought of in conjunction: the act of speaking and passion, rice and cooking, a living body and breathing, perceptual awareness and the senses, and, of course, the stock example of fire and smoke.

The question that Dharmakirti considers concerns the sort of properties, whether observed or unobserved, in similar or dissimilar cases, that can be counted as evidence for asserting a given thesis. How are such properties ascertained? That is, how does one come to know the truth of the major premise? Dharmakirti makes use of the first two examples to argue against the principle that mere observation and non-observation of occurring associations and dissociations is a sufficient ground for sound inferential reasoning. In the case of the act of speaking and passion, observation of their occurring association is just a case of erratic evidence, for at most the act of speaking can serve as ground for inferring the presence of a speech organ and a capacity to communicate (PVSV 12.3), not of passion. Of course, here he is indirectly rejecting the notion that speech requires passion - seen as an affliction - for its cause: thus, buddhas, who are certainly observed to speak, cannot do so on account of something which they have overcome. In the case of rice and cooking, nonobservation in dissimilar cases does not provide sufficient grounds for sound inference either: even though one may observe grains of rice cooking in a cauldron, one cannot thereby infer that all the grains of rice are cooked simply because they happen to be in the cauldron. Indeed, hypothetically speaking, some may be uncooked (PVSV 13.1).

How, then, can one escape the risk that there may be unobserved instances to the contrary, given that observation of a relation between things at a given place and time does not necessarily guarantee that the same relation will occur 
in other places and at other times? For Dharmakirti the solution to this conundrum is appeal to rules of reasoning that best reflect the nature of causally efficient entities: that is, to the so-called natural relation (svabhävapratibandha) between the properties of an inference. As he explains, one cannot infer from a cause to its effect, or from a causal totality (käranasāmagrī) to an effect, because there is always the chance of impending factors preventing the arising of the given effect. Consider, for instance, cases when the rice in the cauldron is clumped. But Dharmakirti does admit that one can infer from the effect to the cause, though only in a restricted case. As he writes in PVSV 12.4, "only an immediate effect enables the inference of a cause, because it is dependent on it."13 The Sanskrit here for "immediate" is näntariyakam, which can also be translated as "inseparable" or "without interval," conveying the sense of tight proximity that is associated with causal-cognitive chains.

For Dharmakirti, thus, an awareness of the causal totality can serve as a legitimate basis only for asserting that effects arise due to a variety of causes and conditions. Such awareness, however, may not be able to establish which specific effect arises due to which specific set of causes. Much like Dignāga before him, Dharmakirti too is concerned with maximizing our predictive capacity to make sound inferences, the ultimate, and obvious, goal of which is achieving desired ends. ${ }^{14}$

Dharmakirti's view of the role of causality for reasoning, then, may be summarized as follows: one can only legitimately infer from the effect to the cause, and only in the case of an immediately arising effect, since even knowing the causal totality for a given effect does not guarantee that impending factors would not preempt its arising. Now, a naturalized account of the kāryānumāna argument would have to take into account at least two things:

1) Empirical evidence that the reason, or that which is to be proven, acquires its evidential status as a result of factors that are inherent to our cognitive architecture, specifically to information processing systems that translate perceptual content into action.

2) A theoretically robust account of how intentional content, as the subjective basis for reasoning, can in turn play a causal role in explaining how acting toward some desired end is successfully accomplished.

As noted above, given different strategies of naturalization some may prove more effective than others. The strategy I favor takes the view that reasons can be naturalized both by bridging the gap between phenomenology and natural science, and by extending the concept of what counts as natural to include also the mental. ${ }^{15}$ The general idea is that perceptual and mental processes have evolved to provide effective and meaningful interaction with the environment. Of course, these are, at best, working hypotheses and play at most a heuristic role. Nevertheless, they do provide an account of reasons that is both scientifically informed and phenomenologically constraining. 
Recall our second leading issue: to say that the truth of the major premise can be known by perception is to put forth a particular view of perception - one which views perceptual awareness as a form of embodied action. On this view, perceptual awareness does requires input stimuli for its activation but the resulting perceptual content depends on a set of preconscious or preattentive processes of selection and grouping operating on the input data. These processes are generally thought to be representational: they re-present schematic components of perceptual experience following sensory-motor modalities. Perceptual awareness is thus inherently projective with the object of perception being the result of interactions between the input stimuli and dynamic information processes that are part of the architecture of sensory systems. ${ }^{16}$

To take just one example: evidence from neuroscience relating to cases of blindsight indicates that achieving a desired end, say navigating around objects in an environment without seeing them, can be achieved in the absence of any perceptual awareness of the objects, so long as the largely unconscious causal mechanisms that regulate sensorimotor intentionality remain functional. The philosophical upshot of this sort of phenomenon is that pragmatic reasoning of the sort that causes an individual to successfully reach an object even without being directly aware of it is possible by virtue of the fact that cognition is embodied and embedded within the environment of which it is a part.

On this account of embodied cognition, direct perceptual awareness, as conceived by the Buddhist, is an effective source of knowledge precisely because it is a form of embodied action. For to perceive is to understand how we cope with the environment we inhabit. We cannot cope very well if we take the world to be a vast agglomeration of entities that lack any reference to subjects of experience. This brings us to our third and final issue: can a careful inspection of the effect be conducive to ascertaining the unique causal totality that is its source?

Dharmakirti argues that an inference from the cause to the effect is unsound. Now, what about inference from the effect to the cause? Consider the typical example of a park ranger: in spotting a column of fire rising above a mountain, she can legitimately infer that there is a fire, but not whether the fire is fueled by redwoods or by eucalypts. On closer inspection, she may detect from the peculiar color and odor of the smoke that it is eucalypts that fuel the fire, but still not know whether the fire was started by lightning or by embers drifting from a campsite. Closer inspection still may reveal that an arsonist in fact started the fire.

But this example, which I adopted and adapted here from Hayes and Gillon (2008), overlooks an important fact: the park ranger's experience. Unless this is her first day on the job, ideally she already has the sort of requisite knowledge and embodied skill demanded by the task at hand: ascertaining the unique causal totality of a given column of smoke. Her perception of smoke happens within a certain horizon of background intuitions about the height and 
distance of the smoke column, the time of day, current weather conditions, the location of campsites, the flammability of various tree species, and a recent history of arsonist attacks. It is this horizon of background intuitions that, on a model of embodied cognition, accounts for the efficacy of the inferential process.

\section{Conclusion}

A central principle of the embodied and enactive cognition paradigm is that at least a subset of our cognitive processes are not entirely internal but rather are co-constituted by external processes that extend into the environment. It is for this reason, I think, that Dharmakirti's käryānumāna argument could be interpreted as a species of what Keijzer and Schouten (2007) describe as process externalism: the view that reasons, as active forms of deliberation and cognitive engagement, depend on - and are continuous with - bodily processes that are embedded in the environment of which we are a part. Such an account steers clear of the typical conundrum of metaphysical interpretations: trying to square how someone like Dharmakīrti can argue for both external realism and some version of epistemic idealism.

\section{Notes}

1 For a review of the various positions that Dharmakirti can be said to endorse, see Siderits (1999), Eltschinger (2010), and Tillemans (2014).

2 For a good overview of core aspects of the Abhidharma project, see Williams (1981), Cox (1995), and Ronkin (2005).

3 Conceived largely as a project of integrating phenomenological and epistemological theories into the framework of the natural sciences, this was also the first study to bring Buddhist philosophy of mind in conversation with the sciences of cognition.

4 This is largely a Quinean conception of naturalism. In his influential analysis of the failure of traditional epistemology to answer the problem of the foundation of our beliefs, Quine (1969) ended with a proposal that we abandon a priori reasoning and devote ourselves instead simply to studying the psychological processes by which we form beliefs. Strong defenders of naturalism, such as Kornblith (1999) and Stich (1990), have argued against rationality as a foundational principle for traditional epistemology. More moderate versions of naturalism, as one finds in Kim (1988) and Goldman (1992), allow for evaluative questions about rationality, justification, and knowledge to be pursued in a traditional manner.

5 See Coseru (2012, ch. 2). 
6 On this aspect of Dharmakirti's thought, see Hayes (1980), Gillon (1991), and Tillemans (2014).

7 See, for instance, Hurley (1998), Noë (2004), Gallagher (2006), and Thompson (2007).

8 See, for instance, MacKenzie (2009) and Chadha (2011).

9 Ganeri, for instance, suggests additional affinities between Dharmakirti's account of perception and theories developed in recent years by Andy Clark and Christopher Peacocke (Ganeri 2011, 238).

10 I address this issue at length in Coseru (2009).

11 I derive this example of pragmatic reasoning from Bell (2001, 46ff.).

12 It may be worth noting here that arguments for the impermanence of sound are framed as Buddhist refutations of the characteristically Mīmāmsaka proof about the infallibility of trustworthy verbal testimony (śabda-pramāna).

13 Translation, slightly altered, per Hayes and Gillon (2008, 340).

14 For now, I leave aside the question whether in framing the kāryānumāna argument as he does, Dharmakīrti's motive is ultimately soteriological. For more on this issue, see Steinkellner (1999).

15 For detailed accounts of how the conception of nature can be opened up to include consciousness and intentionality, see Smith (1999), who mainly uses Gibson's (1979) ecological approach to perception as a model.

16 See Palmer (1999).

\section{References}

Bell, J. 2001. "Pragmatic Reasoning: Pragmatic Semantics and Semantic Pragmatics." In Modeling and Using Context, edited by V. Akman, P. Bouquet, R. Thomason, and R.A. Young, 44-58. London: Springer-Verlag.

Chadha, M. 2011. "Self-awareness: Eliminating the Myth of the 'Invisible Subject.' Philosophy East and West 61(3): 453-467.

Coseru, C. 2009. 'Buddhist 'Foundationalism' and the Phenomenology of Perception.” Philosophy East and West 59(4): 409-439.

Coseru, C. 2012. Perceiving Reality: Consciousness, Intentionality, and Cognition in Buddhist Philosophy. New York: Oxford University Press.

Coseru, C. 2015. "Perception, Causally Efficacious Particulars, and the Range of Phenomenal Consciousness." Journal of Consciousness Studies 22(9-10): $55-82$.

Cox, C. 1995. Disputed Dharmas: Early Buddhist Theories on Existence - an annotated translation of the section on factors dissociated from thought from Sañghabhadra's Nyāyānusāra. Tokyo: The International Institute for Buddhist Studies.

Davidson, D. 1970. “Mental Events." In Experience and Theory, edited by Lawrence Foster and J.W. Swanson, 79-101. London: Duckworth. 
Dharmakīrti. 1957. Pramānavarttika (tshad ma rnam 'grel). In The Tibetan Tripitika, Peking Edition, edited by D.T. Suzuki (P. 5709). Tokyo: Tibetan Tripitika Research Institute.

Dretske, F. 1989. "Reasons and Causes." Philosophical Perspectives 3: 1-15.

Eltschinger, Vincent. 2010. “Dharmakīrti." Revue Internationale de Philosophie 64(3): 397-440.

Gallagher, S. 2006. How the Body Shapes the Mind. New York: Oxford University Press.

Ganeri, J. 2011. "Apoha, Feature-Placing, and Sensory Content." In Apoha: Buddhist Nominalism and Human Cognition, edited by Mark Siderits, Tom Tillemans, and Arindam Chakrabarti, 228-246. New York: Columbia University Press.

Gibson, J.J. 1979. The Ecological Approach to Visual Perception. Dallas: Houghton Mifflin.

Gillon, Brendan S. 1991. "Dharmakīti and the Problem of Induction." In Studies in the Buddhist Epistemological Tradition: Proceedings of the Second International Dharmakirti Conference, Vienna, June 11-16, 1989, edited by E. Steinkellner, 53-58. Vienna: Verlag der Österreichischen Akademie der Wissenschaften.

Goldman, A. 1992. Liaisons: Philosophy Meets the Social and Cognitive Sciences. Cambridge, MA: MIT Press.

Hayes, R. 1980. "Dinnāga's Views on Reasoning (svārthānum āna)." Journal of Indian Philosophy 8(3): 219-277.

Hayes, R. and Gillon, B. 2008. "Dharmakīti on the Role of Causation in Inference as Presented in Pramānavārttika Svopajñavrtti 11-38." Journal of Indian Philosophy 36: 335-404.

Hurley, S. 1998. Consciousness in Action. Cambridge, MA: Harvard University Press.

Katsura, S. 2007. "How Did the Buddhists Prove Something? The Nature of Buddhist Logic." Pacific World 3(9): 63-84.

Keijzer, F. and Schouten, M. 2007. "Embedded Cognition and Mental Causation: Setting Empirical Bounds on Metaphysics." Synthese 158: 109-125.

Kim, J. 1988. "What is 'Naturalized Epistemology'?" In Philosophical Perspectives II: Epistemology, edited by J.E. Tomberlin, 381-406. Atascadero: Ridgeview Publishing Company.

Kornblith, H. 1999. "In Defense of Naturalized Epistemology." In The Blackwell Guide to Epistemology, edited by J. Greco and E. Sosa, 158-169. Oxford: Blackwell.

Lowe, E.J. 2008. Personal Agency: The Metaphysics of Mind and Action. Oxford: Oxford University Press.

MacKenzie, Matthew. 2010. "Enacting the Self: Buddhist and Enactivist Approaches to the Emergence of the Self." Phenomenology and the Cognitive Sciences 9(1): 75-99. 
Noë, A. 2004. Action in Perception. Cambridge, MA: MIT Press.

Palmer, S. 1999. Vision: From Photons to Phenomenology. Cambridge, MA: MIT Press.

Pandeya, R.C., ed. 1989. Pramānavārttikam of Ārya Dharmakirti: With the commentaries Svopajñavrtti of the author and Pramānavārttikavrtti of Manorathanandin. Delhi: Motilal Banarsidass.

Pradhan, P. 1975. Commentary on the Compendium of Superior Knowledge (Abhidharmakośabhāsyam), revised 2nd edition, edited by A. Haldar. Patna: Kashi Prasad Jayaswal Research Institute.

Quine, W.V.O. 1969. "Epistemology Naturalized." In Ontological Relativity and Other Essays. New York: Columbia University Press.

Ronkin, N. 2005. Early Buddhist Metaphysics: The Making of a Philosophical Tradition. London and New York: Routledge-Curzon.

Siderits, M. 1999. "Apohavāda, Nominalism and Resemblance Theories." In Dharmakirti's Thought and Its Impact on Indian and Tibetan Philosophy: Proceedings of the Third International Dharmakirti Conference, Hiroshima, November 4-6, 1997, edited by S. Katsura, 349-362. Vienna: Verlag der Österreichische Akademie der Wissenschaften.

Smith, D.W. 1999. “Intentionality Naturalized?" In Naturalizing Phenomenology, edited by J. Petitot, F.J. Varela, B. Pachoud, and J.M. Roy, 83-110. Stanford: Stanford University Press.

Steinkellner, E., ed. 1967. Dharmakirti's Hetubinduh, Teil 1, tibetischer Text und rekonstruierter Sanskrit-Text. Vienna: Österreichische Akademie der Wissenschaften.

Steinkellner, E. 1999. "Yogic Cognition, Tantric Goal, and Other Methodological Applications of Dharmakīrti's käryānumana theorem." In Dharmakirti’s Thought and Its Impact on Indian and Tibetan Philosophy: Proceedings of the Third International Dharmakirti Conference, Hiroshima, November 4-6, 1997, edited by S. Katsura, 349-362. Vienna: Verlag der Österreichischen Akademie der Wissenschaften.

Stich, S. 1990. The Fragmentation of Reason. Cambridge, MA: MIT Press.

Thompson, E. 2007. Mind in Life: Biology, Phenomenology, and the Sciences of Mind. Cambridge, MA: Harvard University Press.

Tillemans, Tom. 2014. "Dharmakīti." In The Stanford Encyclopedia of Philosophy, edited by Edward N. Zalta. http://plato.stanford.edu/archives/spr2014/entries/ dharmakiirti/

Varela, F.J., Thompson, E., and Rosch, E. 1991. The Embodied Mind: Cognitive Science and Human Experience. Cambridge, MA: MIT Press.

Williams, P. 1981. "On the Abhidharma Ontology." Journal of Indian Philosophy 9: 227-257. 